\title{
The Agony of Being on the Waiting List for an Organ Transplant
}

\section{Reginald Green*}

Nicholas Green Foundation, USA

*Corresponding Author: Reginald Green, Nicholas Green Foundation, USA.
Received: December 23, 2021

Published: January 18, 2022

(C) All rights are reserved by Reginald Green.
Waiting for an organ transplant is one of the most unsettling experiences in the whole of medicine. Why? Well, for one thing, anyone on the waiting list has an advanced terminal illness. If they don't receive a new heart or kidney, liver or lungs or some other vital organ they will die, and probably soon. For another, they have no idea if a new organ will be offered to them at all -- there is a shortage in almost every country in the world -- and, if one is offered, whether it will arrive in time or fit their individual needs.

There is absolutely nothing they can do to speed up the process. Nothing. The feeling of helplessness is complete. Moreover, the offer will have to come from a complete stranger whom they cannot even visualize and who cannot visualize them. Worse still, the organ will have belonged to someone who has just died quite unexpectedly -- from a road accident, perhaps, or a blow to the head -- and whose family, while having to adjust to an emptiness they could never have foreseen, has been willing to put aside its own devastation long enough to give away parts of their loved one's body.

The stakes could scarcely be higher. If the transplant is successful, as in the great majority of cases it is, they will not slowly recuperate but will be bounced back to a healthy and productive life within weeks, even days. For the first time ever, perhaps, they will not have to force air in and out of diseased lungs or they may find they can now play games just like everyone else, get a job, travel, be left alone without fear and a myriad other activities that most people take for granted.

They carry a beeper wherever they go so they can go immediately to the hospital where the donor, now brain dead, is on a ventilator that keeps the blood flowing and the organs viable for several hours or maybe a day. Like all the other balancing acts in transplantation that window of time is -- again that word -- agonizingly short.
I think back over the years to Rina, then 38 years old and living in Los Angeles, whose happy life was shattered when she was divorced, became sick and could no longer do two jobs. In El Salvador, where she grew up in a poor family, she only reached third grade. She was married at 18 , had a miscarriage and a second child who was born two months prematurely. “Medication didn't help and the doctors told me my kidneys will die one day. I didn't know what they were talking about. I didn't have any idea what dialysis was. And I didn't want to know anything about any of it", she told me.

But there was no other solution and she was on dialysis for five years, four hours a day, three days a week. "My mother, who still lives in El Salvador, came with me to the clinic one day when she was visiting. It frightened her so much she couldn't stop crying - all those needles and poor old people. Some don't have an arm or a leg".

She was being drained emotionally. Over the years Bryan, her son, would ask her, "Can you help me with this homework or can we go to the store?" "Not today, honey", she found herself replying time and again, "I have to go to dialysis". Every month she called the hospital: to ask the same thing "Do you know where I am on the list, please?" At home she prayed, "Please, God, give me a few more years. I need to be with my little boy". For years, she struggled to stay at work.

Then one day the phone call came. "We've got a kidney for you. We want you to come in at 8:30 tonight". "I was so excited. I couldn't believe it. But then I thought of something. 'Can I come in tomorrow morning?' I asked. 'I have to arrange for my son to stay with his daddy."' No, she was told, you have to come in tonight. The new kidney would go in early the next day. She began to be scared. 
As soon as she got home she sat down beside Bryan. "He was so thrilled. 'No more dialysis, Mom,' he said, 'never again?' Then I felt I had to say something I'd said to him when I first started dialysis. 'Listen, honey, everything will be okay but I have to tell you, just in case, if I don't come back to the house, you have your daddy to go to. He was so shocked all he could say was, 'Momma, you're coming back to the house, aren't you? You are, aren't you?' So then I told him, 'Of course, I am. How could I leave you?' But when my boyfriend drove me to the hospital that night and Bryan got out of the car to go to his daddy's house, I thought, 'Will I ever see him again?'”.

Everything went well, however. "Color has come back to my face. My hair has a shine to it", Rina says. "When people say, 'You look wonderful,' that's how I feel on the inside too".

Reg Green is the father of Nicholas Green, a seven-year old American boy who was shot in a botched robbery while the family was on holiday in the south of Italy in 1994 and whose organs and corneas he and his wife, Maggie, donated to seven very sick Italians, four of them teenagers. In the following ten years organ donations in Italy, which until then had been almost the lowest among comparable European countries, tripled, a rate of increase no other country has ever come close to. Since then the Greens have campaigned around the world to show families that a simple decision to say 'yes' can save multiple other families from devastation. A made-for-television movie, of their story, starring Jamie Lee Curtis, called "Nicholas' Gift", has been seen by a hundred million people worldwide. Their website is www.nicholasgreen.org.

The photograph below, taken two years after the transplants, shows all seven of Nicholas' recipients plus the five members of the Green family, and is published here by permission of Oggi magazine, Italy.

\section{Assets from publication with us}

- Prompt Acknowledgement after receiving the article

- Thorough Double blinded peer review

- Rapid Publication

- Issue of Publication Certificate

- High visibility of your Published work

Website: www.actascientific.com/

Submit Article: www.actascientific.com/submission.php

Email us: editor@actascientific.com

Contact us: +919182824667

Citation: Reginald Green. "The Agony of Being on the Waiting List for an Organ Transplant". Acta Scientific Women's Health 4.2 (2022): 07-08. 